\title{
Charcot-Marie-Tooth Disease Type 2E
}

National Cancer Institute

\section{Source}

National Cancer Institute. Charcot-Marie-Tooth Disease Type 2E. NCI Thesaurus. Code C134953.

A form of Charcot-Marie-T ooth disease which is inherited in an autosomal dominant manner. It is caused by mutation(s) in the NEFL gene, encoding neurofilament light polypeptide. It results in peripheral axonal neuropathy. 